(RESEARCH ARTICLE)

\title{
Evaluation and follow up patients with diabetes mellitus who attended Sabratha diabetic center
}

Khaled Ali ALawaini 1,*, Hanen Daw Sweed 2, Khalod Mohamed Sawesi 2, Fatma Abdusalam Kamoka 2, Sara Abugalel Alakrme ${ }^{2}$ and Noha Khalifa Abugila ${ }^{2}$

${ }^{1}$ Ph.D. student in the Biochemistry department at Memorial University, Canada.

${ }^{2}$ Higher institute of science and medical technology/Sabratha, Libya.

Publication history: Received on 19 November 2020; revised on 26 November 2020; accepted on 28 November 2020

Article DOI: https://doi.org/10.30574/wjarr.2020.8.2.0451

\begin{abstract}
Background: Diabetes is a public health challenge facing the world. Awareness and long term diabetes have an enormous effect, including cardiovascular disease and microvascular disease. Objective: This study aimed to estimate diabetes incidence and it is complications.
\end{abstract}

Methods: A hundred diabetic patients who attended Galil diabetic center in Sabratha city had participated in this study in May 2013.

Results: The mean age was 56 years old. Diabetes was more prevalent in females than in males (62\%vs38\%). The mean blood glucose concentration was $168 \mathrm{mg} / \mathrm{dl}$, reflecting poor glycemic control, as 16\% of diabetic patients moved to treatment with insulin.

Conclusion: Poor glycemic control means of fasting plasma glucose was $168 \mathrm{mg} / \mathrm{dl}$, and $16 \%$ started to use insulin therapy, along with $15 \%$ had hypertension.

Keywords: Diabetes; Glucose; Sabratha; Females

\section{Introduction}

Diabetes is defined as high blood glucose levels (hyperglycemia) due to defects in insulin secretion, action, or both [1]. Diabetes can be classified as Type 1 diabetes, Type 2 diabetes, gestational diabetes, and other types [2]. Type 1 diabetes is the most common type of diabetes during childhood and adolescence [3]. Whereas Type 2 diabetes mellitus (T2DM) usually occurs in adulthood, particularly after 40 years old [4] and accounted for more than $90 \%$ of diabetic patients $[5,1]$. However, worldwide, Type 1 accounts for roughly $10 \%$ of diabetes [6,1]. Globally, diabetes is expected to rise from 171 million patients in 2000 to 366 million by 2030. [7]. However, the prevalence of diabetes was estimated in many Arabic countries, in Lebanon at approximately 15.8\%, Bahrain (25.5\%), United Arab Emirates (23.3\%), and Saudi Arabia (23.7\%) [8]. In 2000 in Libya, it has been estimated that the number of diabetic patients was 88000 and is expected to reach 245,000 by the year 2030 [9]; likewise, in Libya, diabetic patients had been estimated roughly about $14.1 \%$ [10]. The increased incidence of diabetes mellitus is due to lifestyle changes like decreased physical activity and an unhealthy diet [8]. This study aims to estimate the prevalence of diabetes patients in females and males, awareness, and treatment of DM, using glucose analysis and an interview to assess patients through socioeconomic characteristics.

\footnotetext{
${ }^{*}$ Corresponding author: Khaled Ali Alawaini

Higher institute of science and medical technology/Sabratha, Libya. 


\section{Material and method}

A hundred diabetic patients who attended Galil diabetic center in Sabratha city participated in the study. Sabratha is a city located $60 \mathrm{~km}$ northwest of Tripoli, the capital of Libya. Five ml of venous blood samples were collected in a Sodium fluoride glucose tube to measure plasma glucose concentration. In addition, a questionnaire gathered data on the participants sociodemographic characteristics, including age, gender, physical activity, family history, diabetes complications, and duration of the disease. The study was conducted from May 2013 to June 2013 and all diabetic patients gave their consent.

\section{Results}

Our data showed that the patients ages ranged from 23 to 79 years old, and the mean age was 56 years old.

Table1 shows the prevalence of diabetes between females and males.

\begin{tabular}{|l|l|}
\hline Variable & Results \\
\hline Mean age & 56 years old \\
\hline Males & 38 \\
\hline Females & 62 \\
\hline Total & 100 \\
\hline
\end{tabular}

Table 2 shows the distribution of diabetic patients among age groups.

\begin{tabular}{|l|l|l|}
\hline Age group & Number of cases & Mean of blood glucose concentration \\
\hline $20-34$ & 4 & $129 \mathrm{mg} / \mathrm{dl}$ \\
\hline $35-49$ & 28 & $189 \mathrm{mg} / \mathrm{dl}$ \\
\hline $50-64$ & 40 & $179 \mathrm{mg} / \mathrm{dl}$ \\
\hline $65-80$ & 28 & $174 \mathrm{mg} / \mathrm{dl}$ \\
\hline Total & 100 & \\
\hline
\end{tabular}

Table 3 shows the demographic characteristics of diabetic patients.

\begin{tabular}{|l|l|l|}
\hline Variable & Yes & No \\
\hline Health food & $70(70 \%)$ & $30(30 \%)$ \\
\hline Physical activity & $40(40 \%)$ & $60(60 \%)$ \\
\hline Family history with T2DM & $38(38 \%)$ & $62(62 \%)$ \\
\hline
\end{tabular}

Table 4 shows the disease period in a different age group.

\begin{tabular}{|l|l|}
\hline Disease period & Number of cases \\
\hline $1<$ & $18(18 \%)$ \\
\hline $1-9$ years & $49(49 \%)$ \\
\hline $10-19$ years & $24(24 \%)$ \\
\hline $20-29$ years & $7(7 \%)$ \\
\hline $30-40$ years & $2(2 \%)$ \\
\hline Total & $100(100)$ \\
\hline
\end{tabular}




\section{Discussion}

Our data showed that the majority of patients were females, $62 \%$, whereas only $38 \%$ were males. A similar study in Libya showed that diabetes was higher in females (57\%) than in males (43\%) [5]. The study showed increased blood glucose levels in the 35-49 years old age bracket; the mean blood glucose was $189 \mathrm{mg} / \mathrm{dl}$, confirming that age is a risk factor for the disease. Moreover, most diabetic patients were in the age group between 50-64 years old. Olokoba et al. [11] also mentioned that most diabetic patients are between 45 and 64 years in developing countries. Another important finding in a recent survey is that $38 \%$ of patients had a family history of diabetes; either their father or mother had diabetes. This indicates that there is a strong relationship between genetics and DMT2. If family members is diabetes, other relatives are at high risk of developing the disease, and this risk is enhanced for the close relatives [12]. However, in the northwest area of Libya, in 1999, another study also found a high prevalence of positive family history in $28.2 \%$ out of 15212 diabetic patients. In this study, $60 \%$ of participants were physically inactive, and $30 \%$ ate an unbalanced diet [13]. Furthermore, the prevalence of hypertension was 15\%, 55\% did not visit an optometrist, and 39\% were unfamiliar with diabetes and its complications. However, with this poor control, 16\% started to use insulin. Therefore, ignored diabetes can affect the heart, kidney, nerves and blood vessels.

\section{Conclusion}

Low glycemic control showed by high mean of fasting plasma glucose was $168 \mathrm{mg} / \mathrm{dl}$, and $16 \%$ started to use insulin therapy, along with $15 \%$ had hypertension. More attention, consideration, and patient's knowledge could reduce or prevent diabetes complications.

\section{Compliance with ethical standards}

\section{Acknowledgments}

We are grateful to all the participants in this study and all staff at the diabetic center for their help and corporation.

\section{Disclosure of conflict of interest}

The authors have no conflicts of interest.

\section{Statement of informed consent}

All patients in this study gave their informed consent.

\section{References}

[1] American Diabetes Association. Diagnosis and classification of Diabetes Mellitus. Diabetes Care. 2013; (36):6774.

[2] Njolstad P, Hertel J, Sovik O, Raeder H, Johansson S, Molven A. Progress in diabetes genetics. Tidsskr nor Laegeforen. 2010; 130(11): 1145-9.

[3] Wherrett D, Ho J, Huot C, Legault L, Nakhla M, Rosolowsky E. Type 1 Diabetes in Children and Adolescents. Can J Diabetes. 2013; 42: 234-246.

[4] ALawaini K, Abugila M. The effects of obesity along with other risk factors on type 2 diabetic patients in the northwest of. World Journal of Advanced Research and Reviews. 2020; 08(02): 117-123.

[5] Alawaini K, Abugila M. Prevalence of obesity in diabetic patients in the northwest of Libya. GSC Biological and pharmaceutical sciences. 2020; 12(2): 212-216.

[6] You W, Henneberg M. Type 1 diabetes prevalence increasing globally and regionally: the role of natural selection and life expectancy at birth. BMJ Open Diabetes Research and Care. 2016; 4: 161.

[7] Shuaib WL, Cost J. Anatomy of success: 100 most cited articles in diabetes research. Ther adv Endocrinol metab. 2015; 6(4): 163-173.

[8] Karaoui L, Deeb M, Nasser L, Hallit S. Knowledge and practice of patients with diabetes mellitus in Lebanon: a cross-sectional study. BMC Public Health. 2018; 18: 525. 
[9] Bakoush O, Targ Elgzyri T. Do we have a diabetes epidemic in Libya? Libyan J Med. 2006; (1): 2.

[10] El-Shareif H. Quality of care for type 2 diabetes mellitus in Tripoli Medical Center: a retrospective study of 628 patients. Clinical Diabetology. 2017; (6): 204-210.

[11] Olokoba A, Obateru O, Olokoba L. Type 2 Diabetes Mellitus: A Review of Current Trends. Oman medical journal. 2012; (4): 269-273.

[12] Hegazi R, El-Gamal M, Abdel-Hady N, Hamdy O. Epidemiology of and Risk Factors for Type 2 Diabetes in Egypt. Annals of Global Health. 2015; 6(5): 814-820.

[13] Kadiki O, Roaed R. Epidemiological and clinical patterns of diabetes mellitus in Benghazi, Libyan Arab. Eastern Mediterranean Health journal. 1999; (5)1. 